\title{
Marinococcus luteus sp. nov., a halotolerant bacterium isolated from a salt lake, and emended description of the genus Marinococcus
}

\section{Correspondence \\ Wen-Jun Li \\ wjli@ynu.edu.cn or \\ liact@hotmail.com}

\author{
Yun Wang, ${ }^{1} \dagger$ Lan-Lan Cao, ${ }^{1,2}$ † Shu-Kun Tang, ${ }^{3}$ Kai Lou, ${ }^{1}$ Pei-Hong Mao, ${ }^{4}$ \\ Xiang Jin, ${ }^{4}$ Cheng-Lin Jiang, ${ }^{3} \mathrm{Li}-\mathrm{Hua} \mathrm{Xu}^{3}$ and Wen-Jun $\mathrm{Li}^{3}$ \\ ${ }^{1}$ Xinjiang Institute of Microbiology, Xinjiang Academy of Agricultural Science, Urumqi, Xinjiang \\ 830091, PR China \\ ${ }^{2}$ College of Prataculture and Environment Sciences, Xinjiang Agricultural University, Urumqi, \\ Xinjiang 830052, PR China \\ ${ }^{3}$ The Key Laboratory for Microbial Resources of the Ministry of Education, PR China, and \\ Laboratory for Conservation and Utilization of Bio-Resources, Yunnan Institute of Microbiology, \\ Yunnan University, Kunming 650091, PR China \\ ${ }^{4}$ Institute of Ion Beam Biotechnology, College of Physics Science and Technology, Xinjiang \\ University, Urumqi, Xinjiang 830008, PR China
}

A Gram-positive, aerobic, motile, coccoid, orange-pigmented bacterium, designated strain YIM $91094^{\top}$, was isolated from a salt lake sample collected from Barkol Lake in Xinjiang Province, north-west China. The strain was able to grow at pH 6.0-8.0 (optimal growth at $\mathrm{pH} \mathrm{7.0),} \mathrm{at} \mathrm{10-}$ $37{ }^{\circ} \mathrm{C}$ (optimal growth at $28{ }^{\circ} \mathrm{C}$ ) and in the presence of $0-25 \%(\mathrm{w} / \mathrm{v}) \mathrm{NaCl}$ [optimal growth in the presence of $10-15 \%(\mathrm{w} / \mathrm{v}) \mathrm{NaCl}]$. Phylogenetic analyses based on $16 \mathrm{~S}$ rRNA gene sequences showed that strain YIM $91094^{\top}$ was affiliated with the genus Marinococcus and exhibited levels of sequence similarity of $99.2 \%$ to Marinococcus halotolerans $\mathrm{YIM} 70157^{\top}$ and $99.7 \%$ to Marinococcus halophilus DSM $20408^{\top}$. However, it showed moderately low levels of DNA-DNA relatedness with the above type strains (56.0 and $57.5 \%$, respectively). The peptidoglycan type of strain YIM $91094^{\top}$ was $\mathrm{A} 1 \gamma$, with meso-diaminopimelic acid as the diagnostic diamino acid. MK-7 was the predominant menaquinone and anteiso- $\mathrm{C}_{15: 0}(49.9 \%$ of the total) and anteiso$\mathrm{C}_{17: 0}(29.6 \%)$ were the major cellular fatty acids. The DNA G $+\mathrm{C}$ content was 48.7 mol\%. Strain YIM $91094^{\top}$ possessed chemotaxonomic markers that were consistent with its classification in the genus Marinococcus. On the basis of the data presented, strain YIM $91094^{\top}$ is considered to represent a novel species of the genus Marinococcus, for which the name Marinococcus luteus sp. nov. is proposed. The type strain is YIM $91094^{\top}\left(=\right.$ KCTC $13214^{\top}=$ CCTCC AA $\left.208014^{\top}\right)$. An emended description of the genus Marinococcus is provided.
The genus Marinococcus was established by Hao et al. (1984, 1985) with the description of two species, Marinococcus halophilus and Marinococcus albus. Two additional species have been described, Marinococcus hispanicus (Marquez et al., 1990) and Marinococcus halotolerans ( $\mathrm{Li}$ et al., 2005). M. albus and M. hispanicus have been subsequently reclassified as Salinicoccus hispanicus (Ventosa et al., 1993) and Salimicrobium album (Yoon et al., 2007), respectively. Members of the genus Marinococcus are Gram-positive cocci with MK-7 as the predominant isoprenoid quinone and meso-diaminopimelic acid

†These authors contributed equally to this work.

The GenBank/EMBL/DDBJ accession number for the 16S rRNA gene sequence of strain YIM $91094^{\top}$ is FJ214659. as the diagnostic diamino acid of the cell-wall peptidoglycan. In the present study, we describe a Gram-positive, coccoid bacterium, designated strain YIM $91094^{\mathrm{T}}$, isolated from a salt lake in China. The isolate was considered to be closely related to members of the genus Marinococcus based on 16S rRNA gene sequence comparisons. The results of a polyphasic characterization of strain YIM $91094^{\mathrm{T}}$ are presented.

Strain YIM $91094^{\mathrm{T}}$ was isolated from a soil sample collected from Barkol Lake (GPS coordinates of the sampling site are $43^{\circ} 37^{\prime} 04^{\prime \prime} \mathrm{N} 92^{\circ} 46^{\prime} 37^{\prime \prime} \mathrm{E}$ ). The surface water of Barkol Lake is highly saline, with a total salts concentration of $215-263 \mathrm{~g} \mathrm{l}^{-1}$. Salts include those of $\mathrm{Na}^{+}, \mathrm{K}^{+}, \mathrm{Ca}^{2+}, \mathrm{Mg}^{2+}, \mathrm{Cl}^{-}, \mathrm{SO}_{4}^{2-}, \mathrm{HCO}_{3}^{-}$and $\mathrm{CO}_{3}^{2-} . \mathrm{A}$ $2 \mathrm{~g}$ soil sample was suspended in $18 \mathrm{ml}$ sterile water $(10 \%$ 
$\mathrm{NaCl}$ ) and mixed. Soil particles were allowed to sediment, the liquid phase was diluted $10^{3}$-fold and $100 \mu \mathrm{l}$ samples were spread onto the surface of each cultivation plate and incubated for 1 week at $37{ }^{\circ} \mathrm{C}$. Modified ISP 5 medium was used for selective isolation, and comprised (per litre distilled water): $1 \mathrm{~g}$ L-asparagine, $10 \mathrm{~g}$ glycerol, $5 \mathrm{~g}$ yeast extract, $1 \mathrm{~g} \mathrm{~K}_{2} \mathrm{HPO}_{4}, 5 \mathrm{~g} \mathrm{KNO}_{3}, 100 \mathrm{~g} \mathrm{NaCl}$ and $15 \mathrm{~g}$ agar. The $\mathrm{pH}$ of the medium was adjusted to 7.5. Colonies were picked and repeatedly restreaked onto modified ISP 5 medium until purity was confirmed. Biomass for chemical and molecular studies was obtained by cultivation in shaken flasks (approximately 150 r.p.m.) by using modified ISP 5 medium $[10 \%(\mathrm{w} / \mathrm{v}) \mathrm{NaCl}]$ at $28{ }^{\circ} \mathrm{C}$ for about 1 week. For analysis of fatty acid methyl esters, cell mass of strain YIM $91094^{\mathrm{T}}$ was obtained from agar plates after incubation for 2 days on trypticase soy agar (Difco) containing $10 \% \mathrm{NaCl}$ at $28{ }^{\circ} \mathrm{C}$. M. halophilus DSM $20408^{\mathrm{T}}$ and $M$. halotolerans YIM $70157^{\mathrm{T}}$ were obtained from the DSMZ (the German Collection of Microorganisms and Cell Cultures) and Yunnan Institute of Microbiology (China), respectively. They were used as reference strains for DNA-DNA hybridizations and other parallel phenotypic experiments.

Morphological observations under a transmission electron microscope (model H-800; Hitachi) were performed after the strain had grown to exponential phase on modified ISP 5 medium. The Gram reaction was determined by the $\mathrm{KOH}$ lysis method (Cerny, 1978). Cell motility was confirmed by the presence of turbidity throughout the tube including semi-solid medium (Leifson, 1960). Methyl red and Voges-Proskauer tests were performed as described by Smibert \& Krieg (1981). The temperature range for growth was determined by incubating cells for 1 week on modified ISP 5 medium at $4-55{ }^{\circ} \mathrm{C}$. The $\mathrm{pH}$ growth range was investigated between $\mathrm{pH} 4.0$ and 10.0 at intervals of $1 \mathrm{pH}$ unit, by using the buffer system described by $\mathrm{Xu}$ et al. (2005). Tolerance to chlorides of sodium, potassium and magnesium was tested by using the same basal medium, with the above at concentrations of $0-30 \%$ $(\mathrm{w} / \mathrm{v})$. Catalase activity was determined based on production of bubbles after the addition of a drop of $3 \% \mathrm{H}_{2} \mathrm{O}_{2}$. Oxidase activity was observed by oxidation of tetramethylp-phenylenediamine. Hydrolysis of casein, starch, and Tweens 20, 40, 60 and 80 were determined as described by Cowan \& Steel (1965). Additional metabolic properties were tested by means of the API ID 32E, API $50 \mathrm{CH}$ and API ZYM systems (bioMérieux) according to the manufacturer's instructions. Strips were inoculated with a heavy bacterial suspension in a $10 \%$ salts solution.

Cells of strain YIM $91094^{\mathrm{T}}$ were aerobic, Gram-positive cocci. Optimum growth occurred in the presence of 10$15 \% \mathrm{NaCl}$, at $\mathrm{pH} 7.0$ and at $28{ }^{\circ} \mathrm{C}$ on modified ISP 5 medium. Growth was weak in the absence of $\mathrm{NaCl}$ and was not observed with only $\mathrm{KCl}$ or $\mathrm{MgCl}_{2} \cdot 6 \mathrm{H}_{2} \mathrm{O}$. Strain YIM $91094^{\mathrm{T}}$ was able to grow over a wide $\mathrm{NaCl}$ concentration range $(0-25 \%, \mathrm{w} / \mathrm{v})$ on modified ISP 5 medium, in contrast to the results for M. halophilus DSM $20408^{\mathrm{T}}$ and
M. halotolerans YIM $70157^{\mathrm{T}}$. Table 1 provides a comparison of the taxonomic features of strain YIM $91094^{\mathrm{T}}$ and the two recognized species of the genus Marinococcus.

The peptidoglycan was purified and cell-wall amino acids and peptides in cell-wall hydrolysates were analysed by two-dimensional ascending TLC on cellulose plates by using the solvent systems of Schleifer \& Kandler (1972). Cellular fatty acids were identified as described by Sasser (1990) by using the Microbial Identification System (MIDI). Menaquinones were extracted and purified according to the methods of Minnikin et al. (1984) and were analysed by HPLC (Kroppenstedt, 1982). Polar lipids were extracted, examined by two-dimensional TLC and identified by using standard procedures (Minnikin et al., 1984).

The peptidoglycan contained meso-diaminopimelic acid, which is characteristic of the genus Marinococcus. The predominant menaquinone of strain YIM $91094^{\mathrm{T}}$ was MK-7 $(85.4 \%)$; menaquinone MK- $9\left(\mathrm{H}_{4}\right)(14.5 \%)$ was found as a minor component. The major polar lipids of strain YIM $91094^{\mathrm{T}}$ were diphosphatidylglycerol, phosphatidylethanolamine, phosphatidylcholine, phosphatidylglycerol, phosphatidylinositol mannosides, phosphatidylinositol, two unknown phosphoglycolipids and an unknown phospholipid, the same pattern as reported for M. halophilus DSM $20408^{\mathrm{T}}$. The polar lipid profile of M. halotolerans YIM $70157^{\mathrm{T}}$, by contrast, lacked phosphatidylethanolamine and an unknown phosphoglycolipid. The cellular fatty acid profile of strain YIM $91094^{\mathrm{T}}$ comprised anteiso- $\mathrm{C}_{15: 0}$ (49.9\% of the total), anteiso- $\mathrm{C}_{17: 0}(29.6 \%)$, iso- $\mathrm{C}_{15: 0}$ $(5.9 \%), \mathrm{C}_{16: 0}(5.0 \%)$, iso- $\mathrm{C}_{17: 0}(4.4 \%)$ and iso- $\mathrm{C}_{16: 0}$ $(2.6 \%)$. The above features are consistent with the chemotaxonomic description of the genus Marinococcus.

The phylogenetic position of strain YIM $91094^{\mathrm{T}}$ was determined based on 16S rRNA gene sequence analysis. The 16S rRNA gene was amplified by using oligonucleotide primers complementary to highly conserved regions of bacterial 16S rRNA genes. The forward and reverse primers were 27F and 1492R (Reysenbach et al., 2000). The purified PCR product was sequenced by means of the ABI PRISM BigDye Terminator cycle sequencing kit and an Applied Biosystems model 310 automatic DNA sequencer. Species related closely to strain YIM $91094^{\mathrm{T}}$ were identified by performing sequence database searches via the BLAST program. Sequence data for related species were retrieved from the GenBank/DDBJ/EMBL database. Phylogenetic analysis was performed by using the CLUSTAL_X program (Thompson et al., 1997) and the alignment was corrected manually. Phylogenetic analyses were performed with the neighbour-joining (Saitou \& Nei, 1987), maximumlikelihood (Felsenstein, 1981) and maximum-parsimony (Fitch, 1971) tree-making algorithms. Nucleotide substitution rates ( $K_{\text {nuc }}$ values) were calculated and phylogenetic trees were constructed by using the neighbour-joining method (Saitou \& Nei, 1987) with MEGA version 3.0 (Kumar et al., 2004). The topology of the phylogenetic tree 
Table 1. Differential characteristics between strain YIM $91094^{\top}$ and recognized species of the genus Marinococcus

Taxa: 1, YIM $91094^{\mathrm{T}} ; 2$, M. halotolerans YIM $70157^{\mathrm{T}} ; 3$, M. halophilus DSM $20408^{\mathrm{T}}$. Data for reference strains are from Hao et al. (1984), Li et al. (2005) and the present study. All are Gram-positive cocci. All have cell-wall type based on meso-diaminopimelic acid and MK-7 as the predominant menaquinone. Positive for catalase, hydrolysis of aesculin and acid production from glucose. Negative for: methyl red and Voges-Proskauer tests; indole, melanin and $\mathrm{H}_{2} \mathrm{~S}$ production; hydrolysis of starch, and Tweens 20 and 80; and oxidase, ornithine decarboxylase and arginine dihydrolase. Positive for $\beta$-glucosidase, $\beta$-galactosidase and lipase. All are able to utilize D-galactose, D-glucose, Dmannitol, D-mannose and salicin as sole carbon source, but not adonitol, D-arabitol or inositol. +, Positive; -, negative; $\mathrm{W}$, weakly positive.

\begin{tabular}{|c|c|c|c|}
\hline Characteristic & 1 & 2 & 3 \\
\hline Optimal $\mathrm{NaCl}$ range $(\%, \mathrm{w} / \mathrm{v})$ & $10-15$ & 10 & $5-15$ \\
\hline Growth without salts & $\mathrm{w}$ & + & - \\
\hline $\mathrm{pH}$ range & $6.0-8.0$ & $6.5-9.0$ & $6.0-10.0$ \\
\hline Nitrate reduction & - & + & - \\
\hline \multicolumn{4}{|l|}{ Hydrolysis of: } \\
\hline Casein & - & - & + \\
\hline Gelatin & + & - & + \\
\hline \multicolumn{4}{|l|}{ Enzyme activities } \\
\hline L-Aspartic arylamidase & + & - & - \\
\hline Lysine decarboxylase & - & - & + \\
\hline$\alpha$-Galactosidase & + & - & + \\
\hline$\alpha$-Maltosidase & + & + & - \\
\hline \multicolumn{4}{|l|}{ Acid production from: } \\
\hline Fructose & - & - & + \\
\hline D-Mannitol & - & + & + \\
\hline \multicolumn{4}{|l|}{ Carbon-source utilization } \\
\hline D-Arabinose & + & - & - \\
\hline Dextrin & + & + & - \\
\hline D-Fructose & - & + & + \\
\hline D-Mannose & + & + & - \\
\hline Maltose & - & + & + \\
\hline L-Rhamnose & + & - & - \\
\hline D-Sorbitol & + & - & - \\
\hline \multicolumn{4}{|l|}{ Major fatty acids $(>10 \%)$} \\
\hline anteiso- $\mathrm{C}_{15: 0}$ & 49.9 & 37.4 & 45 \\
\hline anteiso- $\mathrm{C}_{17: 0}$ & 29.6 & 21.1 & 30 \\
\hline iso- $\mathrm{C}_{16: 0}$ & & & 14 \\
\hline Menaquinone system & MK-7, MK-9(H4) & MK-7, MK-6 & MK-7 \\
\hline DNA G $+C$ content $(\mathrm{mol} \%)$ & 48.7 & 48.5 & 46.4 \\
\hline
\end{tabular}

was evaluated by the bootstrap resampling method based on 1000 replicates (Felsenstein, 1985).

An almost-complete 16S rRNA gene sequence (1479 bp) of strain YIM $91094^{\mathrm{T}}$ was obtained. Fig. 1 shows the relationship between the novel strain and its nearest phylogenetic relatives. Levels of $16 \mathrm{~S}$ rRNA gene sequence similarity between strain YIM $91094^{\mathrm{T}}$ and the type strains of M. halophilus and M. halotolerans were 99.7 and $99.2 \%$, respectively. In the phylogenetic tree based on the neighbour-joining algorithm, strain YIM $91094^{\mathrm{T}}$ clustered with the type strains of M. halophilus and M. halotolerans (Fig. 1). The results of $16 \mathrm{~S}$ rRNA gene sequence comparison clearly demonstrated that strain YIM $91094^{\mathrm{T}}$ was a member of the genus Marinococcus. The topologies of phylogenetic trees built by using the maximum-likelihood and maximum-parsimony algorithms were similar to that of the neighbour-joining tree (data not shown).

Genomic DNA was extracted and purified according to the methods described by Li et al. (2007). The DNA base composition was estimated by HPLC (Mesbah et al., 1989). The genomic $\mathrm{G}+\mathrm{C}$ content of the DNA of strain YIM $91094^{\mathrm{T}}$ was $48.7 \mathrm{~mol} \%$. Levels of DNA-DNA relatedness were determined according to the optical renaturation method (De Ley et al., 1970; Huß et al., 1983; Jahnke, 1992). DNA-DNA hybridization experiments were performed in triplicate. Levels of DNA-DNA relatedness between strain YIM $91094^{\mathrm{T}}$ and M. halophilus DSM $20408^{\mathrm{T}}$ and $M$. halotolerans YIM $70157^{\mathrm{T}}$ were 56.0 and $57.5 \%$, respectively, below the $70 \%$ cut-off point recommended for assignment of strains to the same genomic species (Wayne et al., 1987). 


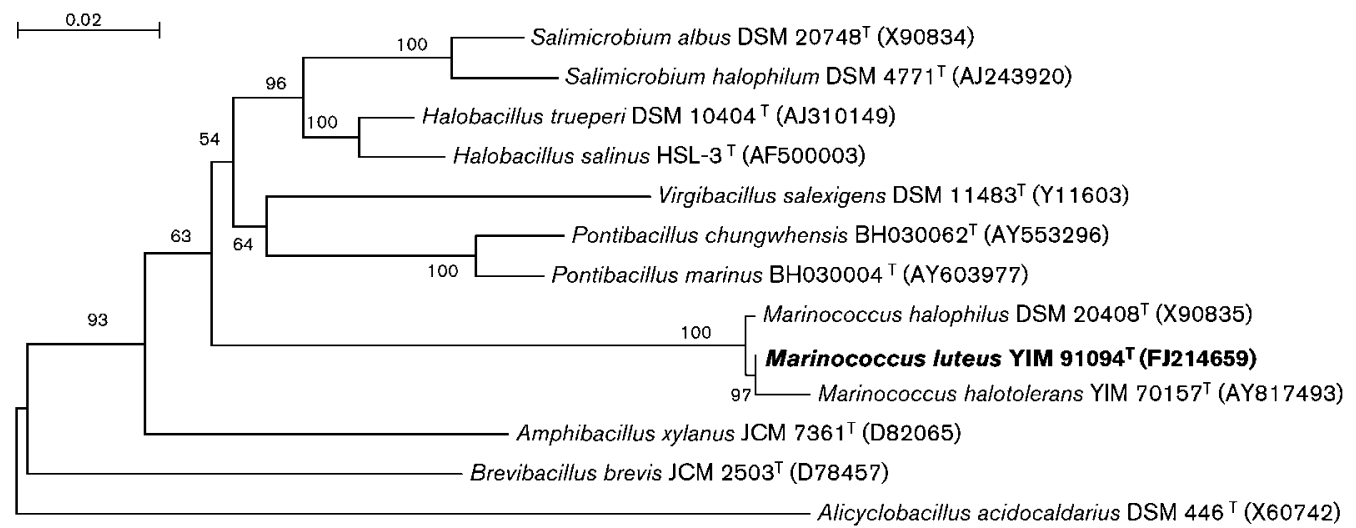

Fig. 1. Neighbour-joining phylogenetic tree based on $16 \mathrm{~S}$ rRNA gene sequences showing the position of strain $\mathrm{YIM} 91094^{\top}$ among related taxa. Numbers at branch points are bootstrap values (percentages of 1000 resamplings; only values $>50 \%$ are shown). The sequence of Alicyclobacillus acidocaldarius DSM $446^{\top}$ was used as outgroup. Bar, $2 \%$ sequence divergence.

The morphological and chemotaxonomic characteristics of the new isolate were consistent with its assignment to the genus Marinococcus. A number of physiological and chemotaxonomic characteristics that can be used to distinguish strain YIM $91094^{\mathrm{T}}$ from its nearest phylogenetic neighbours are presented in Table 1 . On the basis of the phenotypic, chemotaxonomic, phylogenetic and DNADNA hybridization data presented, we consider that strain YIM $91094^{\mathrm{T}}$ represents a novel species of the genus Marinococcus, for which the name Marinococcus luteus sp. nov. is proposed. Additionally, as a consequence of newly reported characteristics not included in the original description of M. luteus YIM $91094^{\mathrm{T}}$, the description of the genus Marinococcus (Hao et al., 1985) needs to be emended.

\section{Emended description of Marinococcus Hao et al. 1985}

The genus is as described by Hao et al. (1985), with the following emendation and modifications. Positive for catalase, hydrolysis of aesculin and acid production from glucose. Methyl red and Voges-Proskauer tests are negative. The major cellular fatty acids are anteiso- $\mathrm{C}_{15: 0}$ and anteiso$\mathrm{C}_{17: 0}$. The polar lipid profile comprises diphosphatidylglycerol, phosphatidylglycerol, phosphatidylcholine, phosphatidylinositol mannosides, phosphatidylinositol, an unknown phosphoglycolipid and an unknown phospholipid or phosphatidylethanolamine. The $\mathrm{G}+\mathrm{C}$ content of the genomic DNA is in the range 46.4-48.7 mol\%.

\section{Description of Marinococcus luteus sp. nov.}

Marinococcus luteus (lu'te.us. L. masc. adj. luteus orange, referring to the colour of the colonies of the type strain).

Cells are Gram-positive, aerobic, non-spore-forming, motile cocci about $0.1-0.5 \mu \mathrm{m}$ in size. Colonies are circular, tangerine-coloured, convex and opaque on modified ISP 5 medium. Grows over a wide range of $\mathrm{NaCl}$ concentration $(0-25 \%, \mathrm{w} / \mathrm{v})$, with optimal growth in the presence of $10-15 \%(\mathrm{w} / \mathrm{v}) \mathrm{NaCl}$. Growth is weak in the absence of $\mathrm{NaCl}$; no growth is observed in the presence of only $\mathrm{KCl}$ or $\mathrm{MgCl}_{2} \cdot 6 \mathrm{H}_{2} \mathrm{O}$. Growth occurs at $10-37{ }^{\circ} \mathrm{C}$ and at $\mathrm{pH}$ 6.0-8.0; optimal growth at $28{ }^{\circ} \mathrm{C}$ and $\mathrm{pH}$ 7.0. Catalase-positive. Negative for oxidase, nitrate reduction, milk peptonization and coagulation, and methyl red and Voges-Proskauer tests. Indole, melanin and $\mathrm{H}_{2} \mathrm{~S}$ are not produced. Negative for lysine and ornithine decarboxylases and arginine dihydrolase. Casein, cellulose, starch, urea, and Tweens 20, 40, 60 and 80 are not hydrolysed. Positive for gelatin liquefaction. In the API ZYM system, positive for alkaline phosphatase, esterase (C4), esterase lipase (C8), lipase (C14), leucine arylamidase, cystine arylamidase, trypsin, $\beta$-glucosidase, $\beta$-galactosidase and $\alpha$-galactosidase, but negative for valine arylamidase, $\alpha$-chymotrypsin, acid phosphatase, naphthol-AS-BI-phosphohydrolase, $\alpha$-glucosidase, $\beta$-glucuronidase, $N$-acetyl- $\beta$-glucosaminidase, $\alpha$ mannosidase and $\alpha$-fucosidase. Acid is produced from aesculin, L-arabinose, D-glucose, glycerol, L-rhamnose and D-xylose (API 50CHB). The following compounds are utilized as sole carbon, nitrogen and energy sources: Darabinose, L-arginine, dextrin, D-galactose, D-glucose, L-lysine, D-mannose, D-mannitol, L-proline, raffinose, Lrhamnose, D-ribose, sucrose, salicin, D-sorbitol, trisodium citrate and D-xylose. The following are not utilized: adenine, adonitol, L-asparagine, D-arabitol, cellobiose, dulcitol, D-fructose, glycerol, glycine, L-histidine, hypoxanthine, inositol, lactose, maltose, xylitol, L-serine, sodium acetate, sodium propionate, trehalose, L-threonine, Ltyrosine and xanthine. The predominant isoprenoid quinone is $\mathrm{MK}-7$; $\mathrm{MK}-9\left(\mathrm{H}_{4}\right)$ is present as a minor component. The polar lipid profile comprises diphosphatidylglycerol, phosphatidylethanolamine, phosphatidylcholine, phosphatidylglycerol, phosphatidylinositol mannosides, phosphatidylinositol, two unknown phosphoglycolipids and an unknown phospholipid. The main 
cellular fatty acids are anteiso- $\mathrm{C}_{15: 0}$, anteiso- $\mathrm{C}_{17: 0}$, iso$\mathrm{C}_{15: 0}, \mathrm{C}_{16: 0}$, iso- $\mathrm{C}_{17: 0}$ and iso- $\mathrm{C}_{16: 0}$.

The type strain, YIM $91094^{\mathrm{T}}\left(=\right.$ KCTC $13214^{\mathrm{T}}=$ CCTCC AA $\left.208014^{\mathrm{T}}\right)$, was isolated from Barkol Lake in Xinjiang Province, north-west China. The DNA G $+\mathrm{C}$ content of the type strain is $48.7 \mathrm{~mol} \%$.

\section{Acknowledgements}

This research was supported by the National Basic Research Program of China (No. 2004CB719601), the Key Project of the Chinese Ministry of Education (No. 206139), the National Natural Science Foundation of China (Nos. 30600001, 30860002 and 30870005), the Open Project Program of the Extremophiles Lab of Xinjiang (No. XJYS0203-2005-01), the Youth Technological Innovation Foundation of Xinjiang Academy of Agricultural Science (No. 2007Q07) and the 973 Pre-research Program of Chain (2008CB417214). W.-J. L. was supported by Program for New Century Excellent Talents in University.

\section{References}

Cerny, G. (1978). Studies on aminopeptidase for the distinction of Gram-negative from Gram-positive bacteria. Eur J Appl Microbiol Biotechnol 5, 113-122.

Cowan, S. T. \& Steel, K. J. (1965). Manual for the Identification of Medical Bacteria. London: Cambridge University Press.

De Ley, J., Cattoir, H. \& Reynaerts, A. (1970). The quantitative measurement of DNA hybridization from renaturation rates. Eur $J$ Biochem 12, 133-142.

Felsenstein, J. (1981). Evolutionary trees from DNA sequences: a maximum likelihood approach. J Mol Evol 17, 368-376.

Felsenstein, J. (1985). Confidence limits on phylogenies: an approach using the bootstrap. Evolution 39, 783-791.

Fitch, W. M. (1971). Toward defining the course of evolution: minimum change for a specific tree topology. Syst Zool 20, 406-416.

Hao, M. V., Kocur, M. \& Komagata, K. (1984). Marinococcus gen. nov., a new genus for motile cocci with meso-diaminopimelic acid in the cell wall; and Marinococcus albus sp. nov. and Marinococcus halophilus (Novitsky and Kushner) comb. nov. J Gen Appl Microbiol 30, 449-459.

Hao, M. V., Kocur, M. \& Komagata, K. (1985). Marinococcus gen. nov. In Validation of the Publication of New Names and New Combinations Previously Effectively Published Outside the IJSB, List no. 19. Int J Syst Bacteriol 35, 535.

Huß, V. A. R., Festl, H. \& Schleifer, K. H. (1983). Studies on the spectrophotometric determination of DNA hybridization from renaturation rates. Syst Appl Microbiol 4, 184-192.

Jahnke, K. D. (1992). BASIC computer program for evaluation of spectroscopic DNA renaturation data from GILFORD SYSTEM 2600 spectrophotometer on a PC/XT/AT type personal computer. J Microbiol Methods 15, 61-73.

Kroppenstedt, R. M. (1982). Separation of bacterial menaquinones by HPLC using reverse phase (RP18) and a silver loaded ion exchanger as stationary phases. J Liq Chromatogr 5, 2359-2367.

Kumar, S., Tamura, K. \& Nei, M. (2004). MEGA3: integrated software for molecular evolutionary genetics analysis and sequence alignment. Brief Bioinform 5, 150-163.
Leifson, E. (1960). Atlas of Bacterial Flagellation. London: Academic Press.

Li, W.-J., Schumann, P., Zhang, Y.-O., Chen, G.-Z., Tian, X.-P., Xu, L.-H., Stackebrandt, E. \& Jiang, C.-L. (2005). Marinococcus halotolerans sp. nov., isolated from Qinghai, north-west China. Int J Syst Evol Microbiol 55, 1801-1804.

Li, W.-J., Xu, P., Schumann, P., Zhang, Y.-Q., Pukall, R., Xu, L.-H., Stackebrandt, E. \& Jiang, C.-L. (2007). Georgenia ruanii sp. nov., a novel actinobacterium isolated from forest soil in Yunnan (China) and emended description of the genus Georgenia. Int J Syst Evol Microbiol 57, 1424-1428.

Marquez, M. C., Ventosa, A. \& Ruiz-Berraquero, F. (1990). Marinococcus hispanicus, a new species of moderately halophilic gram-positive cocci. Int J Syst Bacteriol 40, 165-169.

Mesbah, M., Premachandran, U. \& Whitman, W. B. (1989). Precise measurement of the $\mathrm{G}+\mathrm{C}$ content of deoxyribonucleic acid by highperformance liquid chromatography. Int J Syst Bacteriol 39, 159-167.

Minnikin, D. E., O’Donnell, A. G., Goodfellow, M., Alderson, G., Athalye, M., Schaal, A. \& Parlett, J. H. (1984). An integrated procedure for the extraction of bacterial isoprenoid quinones and polar lipids. J Microbiol Methods 2, 233-241.

Reysenbach, A. L., Longnecker, K. \& Kirshtein, J. (2000). Novel bacterial and archaea lineages from an in situ growth chamber deployed at a Mid-Atlantic Ridge hydrothermal vent. Appl Environ Microbiol 66, 3798-3806.

Saitou, N. \& Nei, M. (1987). The neighbor-joining method: a new method for reconstructing phylogenetic trees. Mol Biol Evol 4, 406425.

Sasser, M. (1990). Identification of bacteria by gas chromatography of cellular fatty acids. USFCC Newsl 20, 16.

Schleifer, K. H. \& Kandler, O. (1972). Peptidoglycan types of bacterial cell walls and their taxonomic implications. Bacteriol Rev 36, 407-477.

Smibert, R. M. \& Krieg, N. R. (1981). General characterization. In Manual of Methods for General Microbiology, pp. 409-443. Edited by P. Gerhardt, R. G. E. Murray, R. N. Costilow, E. W. Nester, W. A. Wood, N. R. Krieg \& G. B. Phillips. Washington, DC: American Society for Microbiology.

Thompson, J. D., Gibson, T. J., Plewniak, F., Jeanmougin, F. \& Higgins, D. G. (1997). The CLUSTAL_X windows interface: flexible strategies for multiple sequence alignment aided by quality analysis tools. Nucleic Acids Res 25, 4876-4882.

Ventosa, A., Marquez, M. C., Weiss, N. \& Tindall, B. J. (1992). Transfer of Marinococcus hispanicus to the genus Salinicoccus as Salinicoccus hispanicus comb. nov. Syst Appl Microbiol 15, 530-534.

Wayne, L. G., Brenner, D. J., Colwell, R. R., Grimont, P. A. D., Kandler, O., Krichevsky, M. I., Moore, L. H., Moore, W. E. C., Murray, R. G. E. \& other authors (1987). International Committee on Systematic Bacteriology. Report of the ad hoc committee on reconciliation of approaches to bacterial systematics. Int J Syst Bacteriol 37, 463-464.

Xu, P., Li, W.-J., Tang, S.-K., Zhang, Y.-Q., Chen, G.-Z., Chen, H.-H., Xu, L.-H. \& Jiang, C.-L. (2005). Naxibacter alkalitolerans gen. nov., sp. nov., a novel member of the family 'Oxalobacteraceae' isolated from China. Int J Syst Evol Microbiol 55, 1149-1153.

Yoon, J. H., Kang, S. J. \& Oh, T. K. (2007). Reclassification of Marinococcus albus Hao et al. 1985 as Salimicrobium album gen. nov., comb. nov. and Bacillus halophilus Ventosa et al. 1990 as Salimicrobium halophilum comb. nov., and description of Salimicrobium luteum sp. nov. Int J Syst Evol Microbiol 57, 2406-2411. 